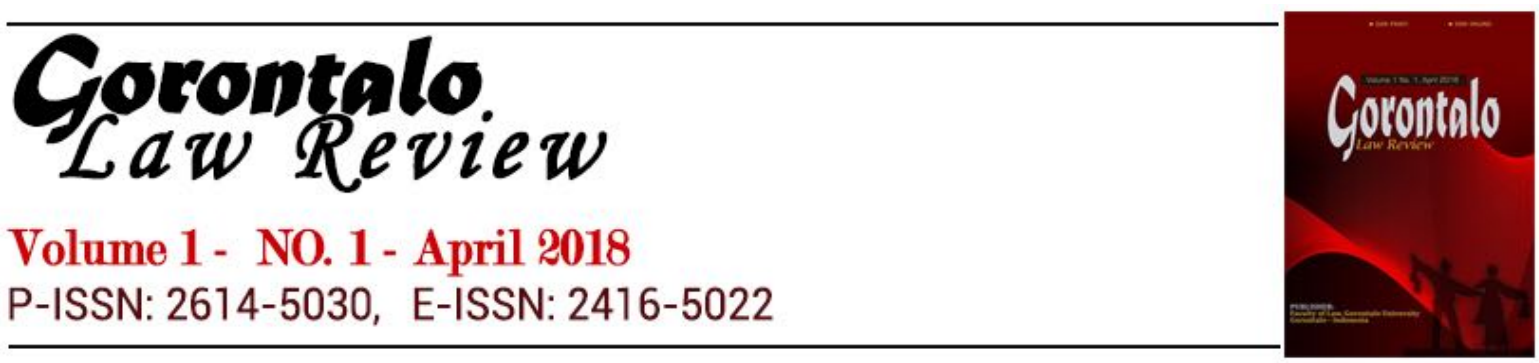

\title{
Efektifitas Fungsi Badan Kepegawaian Daerah Kabupaten Gorontalo dalam Penyelenggaraan Penerimaan Calon Pegawai Negeri Sipil
}

\author{
Nurwita Ismail \\ Ilmu Hukum. Fakultas Hukum Universitas Gorontalo \\ Email : nhurwita.ismail@gmail.com
}

\begin{abstract}
In essence the right of everyone to get the same job and opportunity in government, is one of the instruments in trying to improve prosperity and prosperity of the people. This corresponds to the basic philosophy of the state summarized in Pancasila, where the five precepts of Pancasila should be viewed as one unified whole. Even has been translated in the Constitution of the Republic of Indonesia (UUD) Year 1945, as well as a constitutional basis in governance, nation and state.

The importance of Gorontalo Regency Government / related agencies especially Regional Personnel Agency (BKD) performs acceptance in accordance with the mechanisms stipulated in several Laws and Regulations in particular PP. 43 of 2007, with the expectation that the quantity of civil servants can dominate the quality so that the public expectation of the quality of service and the acceleration of regional development can be fulfilled. Type of research Sociological Juridical. Juridical Sociological Research is a legal research that combines the research of normative law and sociological law research
\end{abstract}

Keywords: Function Evaluation, PNS Receipt

\section{PENDAHULUAN}

Keberhasilan pembangunan nasional tidak lepas dari dedikasi aparatur pemerintah dalam melaksanakan tugasnya dengan baik, karena dalam pelaksanaannya dibutuhkan aparatur pemerintah yang bersih, berwibawa dan mempunyai kemampuan yang tinggi. Sejalan dengan perkembangan Ilmu Pengatahuan dan Teknologi, maka di bidang pemerintahan sekarang ini telah terjadi perubahan yang besar sekali. Salah satu perubahan itu ialah diwujudkannya tata pemerintahan yang demokratis, dan baik.

Upaya untuk mewujudkan tata pemerintahan yang demokratis, bersih dan berwibawa selalu menjadi obsesi bagi rakyat dan pemerintah di zaman modern sekarang ini. Peristiwa dramatis yang membawa kondisi perekonomian kita terpuruk sehingga agak sulit bangkit kembali, merupakan tonggak kesadaran bagi kita semua untuk kembali menata system pemerintahan yang baik. Salah satu unsur pemerintahan yang memperoleh perhatian dalam upaya reformasi itu ialah penataan aparatur pemerintahan yang meliputi kelembagaan birokrasi pemerintahan, system dan penataan manajemen sumber daya pegawai. 
Sesuai dengan otonomi daerah maka peran Badan Kepegawaian Daerah sebagai instansi yang bergerak dan bertugas di bawah Badan Kepegawaian Negara mempunyai kewenangan yang sangat penuh didalam proses penerimaan calon pegawai negeri. Maka dengan adanya Badan Kepegawaian Daerah diharapkan mampu menjamin kelayakan dan kemampuan calon Pegawai Negeri Sipil.

Diera globalisasi sekarang ini peran Pegawai Negeri Sipil sangat menentukan bagi keberhasilan pembangunan di berbagai bidang. Oleh karena itu, perhatian kita perlu diarahkan kepada Peningkatan kualitas sumber daya manusianya yang berfungsi sebagai tenaga penggerak dalam melaksanakan tugas dan tanggung jawab untuk mencapai keberhasilan pembangunan yang sedang digalakkan.

Untuk mendukung pelaksanaan pembangunan di daerah maka pemerintah di daerah perlu menggali potensi yang ada untuk dapat dimaksimalkan dalam proses pembangunan. Salah satu potensi yang perlu ditingkatkan adalah Adanya penerimaan CPNS pada Lingkup Pemerintah, Badan Kepegawaian Daerah atau disingkat dengan Badan Kepegawaian Daerah (BKD) merupakan Leading Sector dalam bidang pengelolaan kepegawaian dan pendidikan dan latihan di Kabupaten Gorontalo. Kedudukan yang demikian menuntut adanya struktur kelembagaan yang respresentative dalam melaksanakan tugas dan fungsi organisasi secara optimal Struktur dan kelembagaan BKD Kabupaten Gorontalo di bentuk dan ditetapkan berdasarkan Undang-undang No. 32 Tahun 2004 tentang Pemerintahan Daerah, Peraturan Daerah Kabupaten Gorontalo No. 20 Tahun 2007 tentang Pembentukan Organisasi dan Tata Kerja Badan Kepegawaian Daerah, Pendidikan dan Pelatihan Kabupaten Gorontalo dan Peraturan Bupati No. 41 Tahun 2007 Tentang Pelaksanaan Peraturan Daerah Kabupaten Gorontalo No. 20 Tahun 2007.

Sejumlah permasalahan juga nampak terjadi diantaranya dalam proses penerimaan CPNS terjadi penyadian data yang salah dan simpang siur serta manipulative yang berdampak pada belum adanya kejelasan (titik terang) pengangkatan bagi CPNS. Walaupun tekanan dapat bervariasi dari situasi kesituasi namum beberapa tekanan dan tantangan yang paling umum di hadapi antara lain :

a. Kebijakan Organisasional;

b. Perencanaan Sumber Daya Manusia

c. Pola kebiasan recruiter

d. Kondisi Lingkungan

e. Rekrutmen Tugas pekerjaan/Job

f. Biaya dan Insentif

Pentingnya Pemerintah Kabupaten Gorontalo/instansi terkait khususnya Badan kepegawaian Daerah (BKD) melaksanakan penerimaan sesuai dengan mekanisme yang diatur dalam beberapa Peraturan Perundang-undangan yang berlaku khususnya PP No. 43 Tahun 2007, dengan harapan bahwa dari kuantitas PNS yang ada dapat mendominasi kualitas sehingga harapan masyarakat akan mutu pelayanan dan percepatan pembangunan daerah dapat terpenuhi.

Sesuai dengan otonomi daerah maka fungsi Badan Kepegawaian Daerah sebagai instansi yang bergerak dan bertugas di bawah Badan 
Kepegawaian Negara mempunyai kewenangan yang sangat penuh didalam proses penerimaan calon pegawai negeri. Maka dengan adanya Badan Kepegawaian Daerah diharapkan mampu menjamin kelayakan dan kemampuan calon Pegawai Negeri Sipil.

\section{KERANGKA TEORI}

Teori Fungsi

Pengertian fungsi menurut Kamus Lengkap Bahasa Indonesia merupakan kegunaan suatu hal, daya guna serta pekerjaan yang dilakukan. Fungsi merupakan sekelompok aktivitas yang tergolong pada jenis yang sama berdasarkan sifatnya, pelaksanaan ataupun pertimbangan lainnya. Definisi tersebut memiliki persepsi yang sama dengan definisi fungsi menurut Sutarto dalam Nining Haslinda Zainal (2008:22), yaitu Fungsi adalah rincian tugas yang sejenis atau erat hubungannya satu sama lain untuk dilakukan oleh seorang pegawai tertentu yang masing-masing berdasarkan sekelompok aktivitas sejenis menurut sifat atau pelaksanaannya.

Sedangkan pengertian singkat dari definisi fungsi menurut Moekijat dalam Nining Haslinda Zainal (2008:22), yaitu fungsi adalah sebagai suatu aspek khusus dari suatu tugas tertentu.

David F. Smith dalam Gibson, Ivancevich, dan Donelly (1993:37) menjelaskan mengenai hubungan antara pekerjaan pegawai, yang dalam hal ini berupa tugas pokok dan fungsi dengan efektivitas pegawai, bahwa :

"Selain masalah praktis dalam hubungan dengan desain pekerjaan, yaitu berkaitan dengan keefektifan dalam istilah ekonomi, politik, dan moneter, akan tetapi pengaruh yang terbesar berkaitan dengan keefektifan sosial dan psikologis pegawai. Pekerjaan dapat menjadi sumber tekanan psikologis dan bahkan gangguan mental dan fisik terhadap seorang pegawai selain sisi positif dari pekerjaan yaitu dapat menghasilkan pendapatan, pengalaman hidup yang berarti, harga diri, penghargaan dari orang lain, hidup yangteratur dan hubungan dengan orang lain".

Penjelasan tersebut di atas dapat kita simpulkan bahwa pekerjaan ataupun TUPOKSI yang ditetapkan untuk suatu jabatan sangat berpengaruh secara langsung terhadap efektivitas pegawai. Efektivitas pegawai dapat dinilai melalui pelaksanaan tugas-tugasnya secara benar dan konsisten. Tugas pokok dan fungsi pegawai merupakan jabaran langsung dari tugas dan fungsi organisasi kedalam jabatan yang dianalisis. Oleh karena itu, untuk dapat menghasilkan tugas pokok dan fungsi yang tepat dan jelas demi meningkatkan efektivitas pegawai dalam upaya pencapaian tujuan organisasi, upaya awal yang harus dilakukan yaitu melaksanakan proses analisis pekerjaan, yaitu proses pengumpulan data organisasi mengenai berhubungan dengan pekerjaan.

\section{METODE PENELITIAN}

3.1 Lokasi Penelitian

Sesuai dengan judul peneliti tentang Efektifitas Fungsi Badan Kepegawaian Daerah Kabupaten Gorontalo dalam penyelenggaraan 
penerimaan CPNS. Maka lokasi penelitian yang dipilih adalah Kantor Badan Kepegawaian Daerah, Pendidikan dan Latihan Kabupaten Gorontalo, pemilihan Lokasi ini dengan alasan bahwa lokasi ini dekat dengan tempat tinggal peneliti serta didasarkan kepada keberadaan Kabupaten Gorontalo sebagai Kabupaten yang memiliki laju perkembangan pembangunan yang serta memiliki banyak prestasi terutama dalam urusan Kepegawaian.

3.2 Teknik Pengumpulan Data

alat yang digunakan untuk pengumpulan data penelitian ini adalah dengan menggunakan daftar pertanyaan (kuesioner) dan wawancara. Penggunaan teknik kuesioner untuk memperoleh data dari responden. Untuk memperoleh data yang diinginkan dibuat daftar pertanyaan dan kemudian diserahkan/dikirim kepada responden untuk mempelajari sekaligus dijawab oleh responden. Bentuk kuesioner yang dibuat adalah dalam bentuk terbuka dan tertutup dengan tujuan agar pencakupannya tidak kaku dan dapat menampung keinginan dari responden yang tidak tercantum dalam kuesioner.

3.3 Definisi Operasional

a. Fungsi adalah rincian tugas yang sejenis atau erat hubungannya satu sama lain untuk dilakukan oleh seorang pegawai tertentu yang masing-masing berdasarkan sekelompok aktivitas sejenis menurut sifat atau pelaksanaannya.

b. Badan Kepegawaian Daerah atau disingkat dengan BKD adalah perangkat daerah yang melaksanakan manajemen Pegawai Negeri Sipil Daerah dalam membantu tugas pokok Pejabat Pembina Kepegawaian Daerah.

c. Calon Pegawai Negeri Sipil adalah Calon aparatur Negara yang bertugas memberikan pelayanan lkepada masyarakat secara professional, adil, jujur, dan merata dalam penyelenggaraan tugas Negara, pemerintahan dan pembangunan

3.4 Teknik Analisis

Setelah data primer diperoleh, maka dilakukan pengeditan data, sehingga keakuratan data dapat diperiksa dan bila ada kesalahan dapat diperbaiki dengan jalan menjajaki kembali kesumber datanya.

Setelah proses pengeditan data selesai dilaksanakan, maka proses selanjutnya pengolahan data yang dilakukan dengan langkah-langkah sebagai berikut:

a. Untuk data yang diperoleh dari hasil penyebaran kuesioner, maka akan dikelompokkan atau diklasifikasikan sesuai dengan kelompok atau unit analisis yang telah ditentukan.

b. Untuk data yang diperoleh dari hasil wawancara dilakukan penyederhanaan, yaitu dengan cara mengklasifikasikan hasil wawancara ke dalam kelompok-kelompok tertentu sesuai dengan unit analisis variabel penelitian yang telah ditetapkan, cross chek kebenaran data yang diperoleh dari responden.

c. Dalam melakukan penafsiran data dilakukan penyilanganpenyilangan antara unit analisis yang satu dengan unit analisis yang lain, apakah data tersebut saling mendukung atau saling bertentangan dan ditarik kesimpulan. 
Kemudian keseluruhan data, baik data primer maupun sekunder dianalisis dengan mempergunakan metode induktif dan deduktif melalui pendekatan kualitatif dengan mempelajari seluruh jawaban yang ada dalam penelitian ini. 


\section{HASIL PENELITIAN}

4.1 Fungsi Badan Kepegawaian Daerah Kabupaten Gorontalo Dalam Penyelenggaraan Penerimaan Atau Pengangkatan Calon Pegawai Negeri Sipi.

Sesuai dengan Peraturan Bupati Gorontalo Nomor 41 Tahun 2007 Tentang Pelaksanaan Peraturan Daerah Kabupaten Gorontalo Nomor 20 Tahun 2007 setiapk bidang, subbidang/subbagian telah mendapat penetapan tugas pokok sebagai acuan dalam penyusunan program kerja dan penilaian kinerja, baik kinerja institusi maupun kinerja personal setiap PNS pada BKD-Diklat Kabupaten Gorontalo itu sendiri.

Yang menjadi Tugas Pokok BKD-Diklat Kabupaten Gorontalo adalah melaksanakan pengelolaan adminstrasi kepegawaian serta melaksanakan mutasi dan kesekretariatan kepegawaian. Untuk menyelenggarakan tugas tersebut, BKD-Diklat Kabupaten Gorontalo mempunyai fungsi sebagai berikut :

a. Pengumpulan dan pengolahan data serta penyiapan peraturan perundang-undangan di bidang kepegawaian;

b. Pengumpulan bahan pelaksanaan ujian dinas dan pemberian penghargaan dan tanda jasa;

c. Pelaksanaan administrasi kepegawaian;

d. Pengumpulan dan pengolahan data serta penyiapan bahan penyusunan program dan petunjuk teknis pembinaan dan pengembangan karir pengawai serta penyelenggaraan pendidikan dan pelatihan;

e. Pelaksanaan dan pengolahan mutasi dan tata usaha kepegawaian serta analisa jabatan;

f. Penyiapan dan pelaksanaan pengadaan Pegawai Negeri Sipil Daerah, kedudukan hukum sesuai dengan norma, standard an prosedur yang diterapkan dalam peraturan perundang-undangan;

g. Penyiapan dan penetapan administrasi kepegawaian dalam pengangkatan kenaikan pangkat, pemindahan dan pemberhentian dari jabatan structural dan fungsional sesuai dengan norma, standar dan prosedur yang ditetapkan dalam peraturan perundang-undangan;

h. Penyiapan dan penetapan norma pension Pegawai Negeri Sipil Daerah sesuai norma, standard an prosedur yang ditetapkan dalam peraturan perundang-undangan;

i. Penyiapan dan penetapan gaji, tunjangna dan kesejahteraan Pegawai Negeri Sipil Daerah sesuai kurikulum pendidikan pelatihan teknis dan fungsional sesuai dengan norma, standar dan prosedur yang ditetapkan dalam peraaturan perundang-undangan;

j. Penyiapan dan Pelaksanaan Pendidikan Dan Pelatihan penjenjangan dan kurikulum pendidikan pelatihan teknis dan fungsional sesuai norma, standard an prosedur yang ditetapkan dalam peraturan perundang-undangan;

k. Penyiapan dan Penetapan Pendidikan Pelatihan Kader, sesuai dengan norma, standar dan prosedur yang ditetapkan dalam peraturan perundang-undangan;

1. Penyelenggaraan administrasi kepegawaian Pegawai Negeri Sipil Daerah secara umum; 
m. Pengelolaan system Informasi Manajemen Kepegawaian Daerah;

n. Penyiapan Informasi kepegawaian daerah kepala Badan Kepegawaian Negara.

Tugas : Sekretariat melaksanakan tugas dibidang kesekretariatan, perencanaan, kepegawaian umum dan keuangan sebagaimana diatur dalam perundanundangan.

Fungsi :

a. Penyusunan program unit berdasarkan pedoman sebagai acuan pelaksanaan tugas;

b. Pelaksanaan tugas pengelolaan adminstrasi di bidang kesekretariatan berdasarkan pedoman untuk peningkatan pelayanan;

c. Pelaksanaan tugas di bidang kepegawaian berdasarkan petunjuk untuk tertibnya penataan administrasi kepegawaian unit;

d. Pelaksanaan tugas dibidang perlengkapan sebagai kebutuhan kelancaran kegiatan unit;

e. Pelaksanaan tugas pengelolaan administrasi keuangan berdasarkan Rencana Anggaran Satuan Kerja/Dokumen Anggaran Satuan Kerja untuk tertibnya adminstrasi keuangan.

f. Pengkoorian pelaksanaan tugas dengan kepala-kepala bidang melalui rapat/pertemuan untuk penyatuan pendapat.

g. Penyusunan laporan pelaksanaan tugas secara berkala sebagai bahan evaluasi;

h. Pelaksanaan fungsi-fungsi lainnya sesuai dengan tugas dan kewenangan kedinasan.

Tugas setiap Sub bagian:

a) Sub Bagian Keuangan mempunyai tugas menyusun anggaran berdasarkan petunjuk pelaksanaan/petunjuk teknis sebagai pedoman pelaksanaan kegiatan unit, serta tugas-tugas lain sesuai fungsi kedinasan;

b) Sub Bagian Umum dan Kepegawaian melaksanakan tugas pengolahan perlengkapan barang dan kepegawaian berdasarkan pedoman, menyusun rencana pengadaan barang dan rencana pengadaan pegawai sesuai kebutuhan, mengelola urusan rumah tangga unit, serta tugastugas lain sesuai fungsi kedinasan;

c) Sub Bagian Penyusunan Program melaksanakan tugas menyiapkan penyusunan program tahunan berdasarkan petunjuk pelaksanaan kegiatan unit, mengkoordinasikan pelaksanaan tugas dengan sub-sub bidang melalui rapat, serta tugas-tugas lain sesuai fungsi kedinasan.

b) Tugas Pokok dan Fungsi Bidang Pengolahan Data dan Informasi Kepegawaian

Tugas : melaksanakan tugas dibidang pengolahan data system informasi kepegawaian sebagaimana yang diatur dalam perundang-undangan.

Fungsi :

a. Penyusunan kebijakan teknis pengolahan data dan informasi kepegawaian (SIMPEG).

b. Penghimpunan data kepegawaian yang komprehensif untuk mengetahui gambaran keadaan PNS secara keseluruhan. 
c. Pelaksanaan pemutahiran dan atau aktualisasi data serta informasi secara actual dan faktual.

d. Penyusunan laporan hasil pelaksanaan tugas secara berkala sebagai bahan evaluasi.

e. Penyusunan rencana kegiatan pengolahan data dan informasi kepegawaian sesuai kebutuhan untuk menjadi program unit.

f. Pelaksanaan fungsi-fungsi lainnya sesuai dengan tugas dan kewenangan kedinasan.

Tugas setiab Sub Bidang :

1. Subbidang Pengolahan Data dan Pelaporan mempunyai tugas melaksanakan tugas di bidang pengolahan data dan system informasi kepegawaian berdasarkan peraturan perundang-undangan, serta tugastugas lain sesuai fungsi kedinasan.

2. Subbidang Sistem Informasi dan Manajemen Kepegawaian mempunyai tugas melaksanakan tugas di bidang pengolahan system informasi menajemen kepegawaian berdasarkan petunjuk pelaksanaan (Juklak) dan Petunjuk Teknis (Juknis), serta tugas-tugas lain sesuai fungsi kedinasan.

c) Tugas pokok dan fungsi bidang mutasi pengawai

Tugas : melaksanakan tugas di bidang mutasi Pegawai Negeri Sipil sebagaimana diatur dalam perundang-undangan.

Fungsi :

a. Penyusunan kebijakan teknis pengangkatan, pemindahan. Pemberhentian dan kesejahteraan pegawai sesuai kebutuhan sebagai dasar pelaksanaan tugas.

b. Pengumpulan data jabatan sesuai tingkatannya untuk mengetahui gambaran keadaan Pegawai Negeri Sipil sejak pengangkatan pertama dalam jabatan tertentu sampai dengan pension.

c. Penganasilaan data jabatan berdasarkan pola karir, perstasi kerja, penilaian dan tangung jawab untuk penetapan pengankatan dalam jabatan, pemindahan dan pemberhentian Pegawai Negeri Sipil.

d. Penyusunan rencana keigatan mutasi dan pension Pegawai Negeri Sipil sesuai kebutuhan untuk menjadi program unit.

e. Penelitian usulan pengangkatan, pemindahan dan pemberhentian Pegawai Negeri Sipil dalam jabatan sesuai jenis dan tingkatannya untuk kesejahteraan pegawai.

f. Penyusunan laporan hasil pelaksanaan tugas secara berkala sebagai bahan evaluasi.

g. Pelaksanaan fungsi-fungsi lainnya sesuai tugas dan kewenangan kedinasan.

Tugas setiap Sub Bidang :

1. Sub Bidang Pengkajian dan Kepangkatan mempunyai tugas melaksanakan pengolahan penggajian dan kepangkatan bagi Pegawai Negeri Sipil dalam jabatan berdasarkan Petunjuk Pelaksanaan (Juklak) dan Petunjuk Teknis (Juknis), serta tugas-tugas lain sesuai fungsi kedinasan.

2. Sub Bidang Mutasi dan Pensiun mempunyai tugas malaksanakan tugas di Bidang Kepangkatan, Pemindahan dan Pemberhentian Pegawai Negeri Sipil dalam jabatan berdasarkan Petunjuk Pelaksanaan (Juklak) dan 
Petunjuk Teknis (Juknis), serta tugas-tugas lain sesuai fungsi kedinasan.

d) Tugas Pokok dan Fungsi Bidang Pembinaan Pegawai

Tugas : melaksanakan tugas di bidang perencanaan dan pembinaan Pegawai Negeri Sipil berdasarkan peraturan perundang-undangan untuk kelancaran pelaksanaan tugas.

Fungsi :

a. Penyusunan kebijakan teknis bidang pembinaan pengawi sesuai kebutuhan sebagai dasar pelaksanaan tugas.

b. Pengumpulan data dan informasi guna menyusun rencana program dan kegiatan bagi penegakan disiplin Pegawai Negeri Sipil dan peningkatan kesejahteraan pegawai.

c. Pelaksanaan sosialisasi ketentuan perundang-undangan yang berkenan dengan pembinaan disiplin Pegawai Negeri Sipil, pengewaluasian dan menitoring terhadap pelaksanaannya.

d. Penelitian, pengkajian dan pemberian telaahan kepada pimpinan mengenai penjatuhan hukuman disiplin Pegawai Negeri Sipil.

e. Penelitian terhadap proses pelaksanaan cuti, pemilihan pegawai berprestasi, pengurusan satya lencana dan kegiatan lainnya yang berhubungan dengan peningkatan kesejahteraan Pegawai Negeri Sipil.

f. Penyusunan laporan hasil pelaksanaan tugas secara berkala sebagai bahan evaluasi.

g. Pelaksanaan fungsi-fungsi lainnya sesuai tugas dan kewenangan kedinasan.

Tugas setiap sub bidang :

1. Sub Bidang Pembinaan Disiplin Pegawai mempunyai tugas melaksanakan pembinaan, pengawasan dan pengangkatan disiplib pegawai berdasarkan ketentuan perundang-undangan, melakukan pengendalian Pegawai Negeri Sipil secara berjenjang untuk peningkatan disiplin, serta tugas-tugas lain sesuai fungsi kedinasan.

2. Sub Bidang Penilaian dan Kesejahteraan melaksanakan tugas dibidang penilaian dan kesejahteraan Pegawai Negeri Sipil berdasarkan Petunjuk Pelaksanaan (Juklak) dan Petunjuk Teknis (Juknis), menghimpun data, informasi dan Peraturan Perundang-undangan yang berkaitan dengan penilaian kesejahteraan Pegawai Negeri Sipil, menyusun kebijakan teknis penilaian dan kesejahteraan Pegawai Negeri Sipil, melakukan penilaian, monitoring kinerja individual Pegawai Negeri Sipil dalam rangka penilaian pegawai berprestasi, malakukan koordinasi, sinkronisasai dan

3. Harmonisasi dengan seluruh satuan kerja dan pihak terkait lainnya dalam hal penilaian dan pengembangan kesejahteraan Pegawai Negeri Sipil, serta tugas-tugas lain sesuai fungsi kedinasan.

e) Tugas Pokok dan Fungsi Bidang Pendidikan, Pelatihan dan Pengembangan Pegawai.

Tugas : menyusun kebijakan teknis dibidang pendidikan dan pelatihan dan pengembangan Pegawai Negeri Sipil sebagaimana yang diatur dalam peraturan perundang-undangan.

Tugas Setiap Sub Bidang :

1. Sub Bidang Pendidikan dan Pelatihan mempunyai tugas melaksanakan tugas menyusun kebijakan teknis pelaksanan pendidikan pelatihan, 
penjenjangan teknis dan fungsional Pegawai Negeri Sipil, mempersiapkan sarana dan prasarana pendidikan pelatihan prjabatan, penjenjangan, ujian dinas dan ujian Penyesuaian Pegawai Negeri Sipil, mengolah adminstrasi pendidikan dan pelatihan secara sistematis, membuat laporan hasil pelaksanaan tugas secara berkala sebagai bahan evaluasi, serta tugas-tugas lain sesuai fungsi kedinasan.

Sub Bidang Pengembangan Pegawai mempunyai tugas melaksanakan tugas menyusun rencana kegiatan pengembangan pegawai dalam rangka peningkatan kapasitas dan kompetensi Pegawai Negeri Sipil, membuat laporan hasil pelaksanaan tugas secara berkala sebagai bahan, serta tugas-tugas lain sesuai fungsi kedinasan.

Jenis-Jenis Pelayanan Adminstrasi Kepegawaian Di BKD-Diklat Kabupaten Gorontalo.

1. Kegiatan Bidang Mutasi Pegawai :
a. Kenaikan Pangkat PNS
b. Mutasi PNS
c. Pengurusan Kenaikan Gaji Berkala Fungsional Guru, Struktural dan Fungsional Non-Guru.
d. Kartu Pegawai
e. Pension dan Taspen
f. Kartu Suami (Karsu) dan Kartu Istri (Karis)

2. Kegiatan Bidang Pembinaan Pegawai:
a. Sumpah dan Janji PNS
b. Penanganan kasus dilingkungan Kabupaten Gorontalo
c. Penghargaan Satyalencana
d. Cuti PNS
e. Kegiatan Road Show manajemen kepegawaian daerah

3. Kegiatan Bidang Diklat dan Pengembangan Pegawai :
a. Kegiatan ujian dinas dan penyesuaian ijazah
b. Pemberian izin belajar dan tugas belajar
c. Penerimaan Calon Praja IPDN

4. Kegiatan Bidang Pengolahan Data dan Informasi Kepegawaian:
a. Kegiatan peremajaan data kepegawaian
b. Kegiatan verifikasi dan pengumpulan data kepegawaian
c. Kegiatan pemotretan KPE (Kartu Pegawai Elektronik)
d. Kegiatan konversi dan perbaikan NIP
e. Kagiatan seleksi perpanjangan Tenaga Kontrak

Fungsi Badan Kepegawaian Daerah Dalam Penerimaan Atau Pengangkatan Calon Pegawai Negeri Sipil

Peranan pemerintah dalam menyelenggarakan tugas dan fungsinya dituntut untuk memenuhi asas-asas umum pemerintahan yang baik, salah satu tugas pokok pemerintah yang sangat penting adalah memberikan pelayanan kepada publik. Hal ini dimaksudkan bagi pemberian jasa baik oleh pemerintah, masyarakat, swasta, untuk memenuhi kebutuhan dan kepentingan masyarakat.

Sesuai dengan otonomi Daerah Kabupaten Gorontalo, maka fungsi Badan Kepegawaian Daerah sebagai instasi yang bergerak dan bertugas di bawah Badan Kepegawaian Negara mempunyai kewenangan yang sangat penuh didalam proses penerimaan calon Pegawai Negeri Sipil. 
Berdasarkan data kuisioner yang diberikan kepada responden dan hasil wawancara dengan narasumber atau informan, tentang fungsi Badan Kepegawaian Daerah, Pendidikan dan Pelatihan Kabupaten Gorontalo dalam penyelenggaraan penerimaan Calon Pegawai Negeri Sipil kemudian kemudian ditetapkan menjadi PNS masih dinilai kurang tetap oleh masyarakat. Untuk lebih jelasnya dapat dilihat pada tabel berikut:

Tabel 1 : Kinerja BKD-Diklat dalam penyelenggaraan penerimaan CPNS

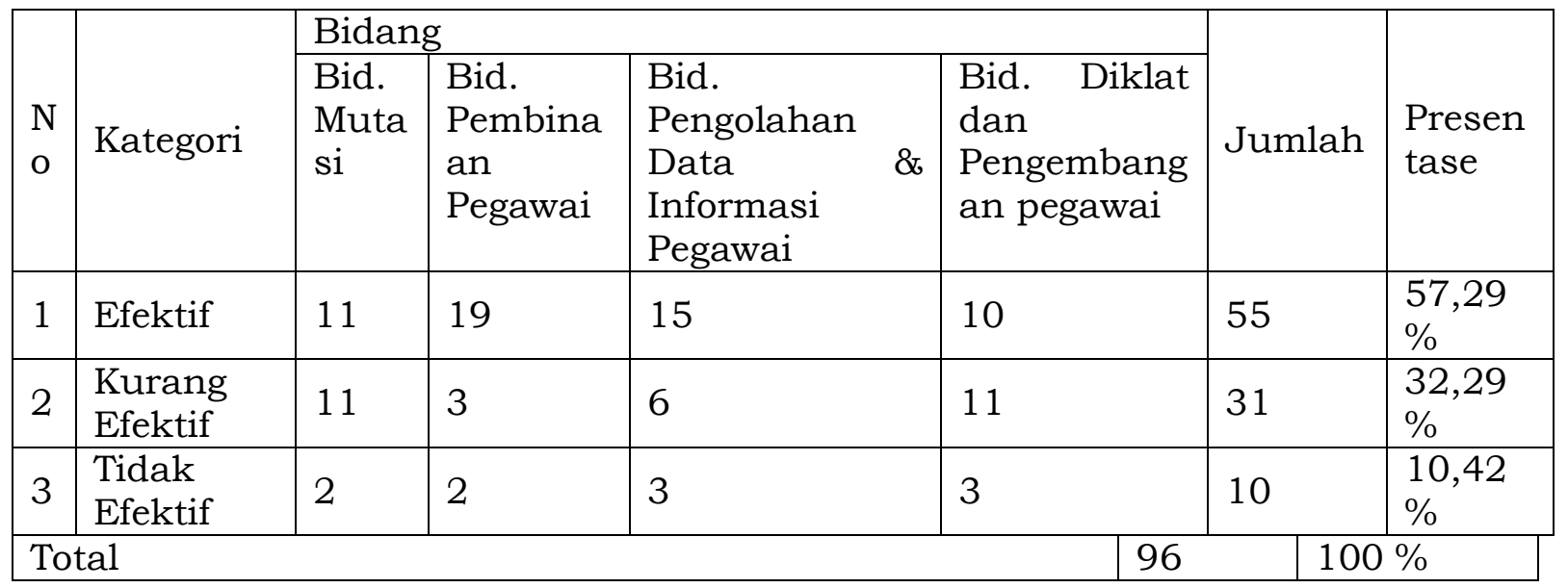

Sumber : Data Primer setelah diolah, 2014

Tabel diatas menerangkan bahwa dari data Quisioner 96 orang, lebih besar responden menilai bahwa kinerja BKD-Diklat Kabupaten Gorontalo baik terbukti bahwa 55 orang atau 57,29\%. Sedangkan 31 orang atau $32,29 \%$ responden minilai bahwa kinerja BKD-Diklat Kab. Gorontalo masih kurang baik, selain itu 10 orang atau 10,41\% responden menilai bahwa kinerja BKD-Diklat tidak baik. Dari data diatas, peneliti berkesimpulan bahwa peran pemerintah lebih khusus lagi BKD-Diklat Kab. Gorontalo masi kurang efektif

Kebijakan penerimaan Pegawai Negeri Sipil diatur oleh Peratruan pemerintah Nomor 98 Tahun 200 jo Peraturan Pemerintah Nomor 11 Tahun 2002 Tentang Pengadaan Pegawai Negeri Sipil , pada pasal (1) menyatakan bahwa: "pengadaan pegawai negeri sipil adalam untuk mengisi formasi yang lowong”.

Ketentuan ini jelas mengatur bahwa pengangkatan atau pengaan Pegawai Negeri Sipil untuk dikerjakan senaganya dalam mendukung pelaksanaan tugas dan fungsi organisasi tersebut. secara prinsip Penerimaan Pegawai Negeri Sipil dilaksanakan sesuai dengan kebutuhan organisasi dan lebih mengutamakan kualitas daripada kuantitas. Penerimaan pegawai menggunakan Zero Growth dimana penerimaan pegawai didasarkan untuk mengganti pegawai negeri yang pensiun, jadi penerimaan tidak mesti tiap tahun.

Pengangkatan tenaga honorer menjadi CPNS dilakukan secara bertahap dari tahun anggaran 2005 dan paling lambat tahun anggaran 2009 berdasarkan Peraturan Pemerintah No. 48 Tahun 2005 Jo Peraturan Pemerintah Tahun 2012 Tentang Pengangkatan Tenaga Honorer Menjadi Calon Pegwai Negeri Sipil. Dari alokasi sebanyak 96 orang, Bedasarkan hasil 
pendataan dan verifikasi berkas maka ditetapkan sebanyak 89 orang yang dialihkan sebagaimana Keputusan Bupati Gorontalo No. 374/08/VIII/2009 Tentang Pengadaan Tenaga Honorer dianggakat menjadi Pegwai Negeri Sipil Daerah Formasi tahun 2009 di Kabupaten Gorontalo. Untuk lebih jelasnya dapat dilihat pada tabel dibawah ini:

Tabel 2 : TENAGA honorer yang terangkat menjadi CPNS tahun 2009

\begin{tabular}{|l|l|l|c|}
\hline No & Pendidikan/Golongan & Jumlah & Presentase \\
\hline 1 & Pend. S1 / III / a & 4 Orang & $4,49 \%$ \\
\hline 2 & Pend. SMA / II / a & 72 Orang & $80,89 \%$ \\
\hline 3 & Pend. SMP / I/c & 8 Orang & $8,98 \%$ \\
\hline 4 & Pend. SD / I/ a & 4 Orang & $4,49 \%$ \\
\hline
\end{tabular}

Sumber Data: BKD Diklat Kab. Gorontalo Tahun 2009

Dari tabel diatas, untuk formasi tenaga honorer dari alokasi 96 orang, yang ditetapkan 89 orang namum yang memperoleh nomor induk pegawai dan diangkat menjadi Calon Pegawai Negeri Sipil hanya 88 orang, sedangkan 8 orang yang tidak ditetapkan menjadi CPNS. Hal tersebut dikarenakan antara lain:

1. Telah lulus melalui formasi umum di daerah lain

2. Sudah tidak menjadi tenaga honor

3. Tidak dapat melengkapi berkas persyaratan

Berdasarkan Peraturan Pemerintah No. 56 Tahun 2012 Tentang Perubahan Kedua atas Peraturan Pemerintah No. 48 Tahun 2005 Tentang Pengangkatan Tenaga Honorer menjadi calon pegawai Negeri Sipil. Dalam Pasal 1 tentang perubahan pasal 3 huruf (a) Peraturan Pemerintah Tahun 2005 "bagi tenaga honor yang dibiayai dari anggaran pendapatan dan belanja daerah untuk mengisi formasi tahun anggaran 2012".

Tenaga honorer yang terangkat mejadi CPNS kategori 1 sesuai Peraturan Pemerintah No. 56 Tahun 2012 Tentang Pengangkatan Tenaga Honorer Menjadi Calon Pegawai Negeri SIpil dilingkungan Pemerintah Kabupaten Gorontalo Tahun 2012 sebanyak 5 orang yang lulus dari 42 yang ditetapkan masuk dalam alokasi formasi CPNS. Untuk lebih jelas dapat dilihat pada tebel berikut :

Tabel 3 : Tenaga Honorer menjadi CPNS Kategori 1 tahun 2012

\begin{tabular}{|l|l|l|l|l|}
\hline No & $\begin{array}{l}\text { Bidang tugas dan } \\
\text { keahlian }\end{array}$ & Pangkat/Golongan & Jumlah & Presentase \\
\hline 1 & Tenaga Pendidik & Pend. S1/III/a & 1 & $40 \%$ \\
\hline 2 & Tenaga Teknis & Pend. SMP/I/c & 1 & $40 \%$ \\
\hline 3 & Tenaga Teknis & Pend. SD/I/a & 3 & $60 \%$ \\
\hline
\end{tabular}

Sumber Data: BKD-Diklat Kab. Gororontalo 2014

Berdasarkan data hasil penelitiah dari BKD-Diklat Kab. Gorontalo pengangkatan CPNS 5 tahun terakhir, terhitung mulai tahun 2009 dan 2010, sedangakan untuk tahun anggaran 2011-2012 Pemerintah Kabupaten Gorontalo belum menyelenggarakan penerimaan atau pengangkatan CPNS untuk pelamar umum. Dari hasil wawancara penulis dengan narasumber Bapak Suwiryo Selaku Pegawai di bidang pembinaan pegawai, hal tersebut merupakan implementasi atas Moratorium PNS (Menpan,Mendagri,\& Menkeu). Isi Moratorium antara lain : 
1. Penghentian sementara pengangkatan CPNS

$>1$ September 2011 sampai 31 Desember 2012

$>$ Kecuali Pemda yang Anggaran Belanja Pegawai < 50\% APBD, Khusus :

- Tenaga Pendidik

- Dokter dan Perawat

- Jabatan Bersifat Khusus \& mendesak

2. Pengangkatan Tenaga Honor (K1/K2) menjadi PNS

$>$ RPP tentang pengangkatan $\mathrm{TH}$ tertinggal belum ditetapkan

$>$ Tenaga Honor Kategori $1 \longrightarrow$ seleksi administrasi

$>$ Tenaga Honor Kategori $2 \longrightarrow$ seleksi administrasi dan ujian tertulis

Tahun anggaran 2009 formasi yang ditetapkan untuk pelamar umum sebanyak 470 orang. Namun pelamar umum yang terangkat menjadi CPNS sebanyak 467, sedangkan sisanya 3 formasi tidak terisi karena tidak ada palamar pada formasi yang ditentukan yakni formasi Dokter umum, Dokter Gigi, dan Penyuluh Peternakan masing-masing 1 orang. Untuk lebih jelas dapat dilihat pada tabel dibawah ini:

Tabel 4 : rincian pelamar umum yang terangkat menjadi calon pegawai negeri sipil tahun 2009 sesuai bidang tugas dan keahlian.

\begin{tabular}{|c|c|c|c|}
\hline No & Bidang Tugas dan Keahlian & Jumlah & presentase \\
\hline 1 & \multicolumn{2}{|l|}{ TENAGA PENDIDIKAN } & \multirow{6}{*}{$48.93 \%$} \\
\hline & Guru TK Negeri & 10 & \\
\hline & Guru SD Negeri & 100 & \\
\hline & Guru SMP Negeri & 63 & \\
\hline & Guru SMA Negeri & 26 & \\
\hline & Guru SMK Negeri & 31 & \\
\hline 2 & \multicolumn{2}{|l|}{ TENAGA KESEHATAN } & \multirow{12}{*}{$29.36 \%$} \\
\hline & Dokter Umum/Dokter Gigi & 8 & \\
\hline & Apoteker & 2 & \\
\hline & Pengawas Farmasi dan Makanan & 3 & \\
\hline & Penyuluh Kesehatan Masyarakat & 11 & \\
\hline & Perawat & 68 & \\
\hline & Teknisi elektromedis & 2 & \\
\hline & Nutrisionis & 7 & \\
\hline & Bidan & 27 & \\
\hline & Pranata laboratorium kesehatan & 2 & \\
\hline & Sanitarian & 5 & \\
\hline & Perawat Gigi & 3 & \\
\hline 3 & \multicolumn{2}{|l|}{ TENAGA TEKNIS } & \multirow{7}{*}{$21.06 \%$} \\
\hline & Penyuluh pertanian & 11 & \\
\hline & Penyuluh perikanan & 4 & \\
\hline & Penyuluh peternakan & 2 & \\
\hline & Penyuluh kehutanan & 3 & \\
\hline & Auditor, analisis kuangan & 3 & \\
\hline & pengembangan & 2 & \\
\hline
\end{tabular}




\begin{tabular}{|c|c|c|}
\hline keparawisataan & & \\
\hline Perencana & 3 & \\
\hline $\begin{array}{l}\text { Pengevaluasi dan penyusunan } \\
\text { program }\end{array}$ & 4 & \\
\hline $\begin{array}{l}\text { Penilai PBB, pengolahan data } \\
\text { perindak dan koperasi }\end{array}$ & 4 & \\
\hline $\begin{array}{lrr}\text { Perencana, intruktur, } & \text { penguji } \\
\text { kenderaan } & \text { bermotor } & \text { dan } \\
\text { pemeliharaan } & \text { sarana } & \text { dan } \\
\text { prasarana fisik } & & \end{array}$ & 13 & \\
\hline $\begin{array}{l}\text { Pengumpul data lalu lintas } \\
\text { perikanan }\end{array}$ & 2 & \\
\hline $\begin{array}{l}\text { Perencana UU, auditor, penyuluh } \\
\text { hukum, analisis kepegawaian }\end{array}$ & 6 & \\
\hline Programer, teknisi computer & 5 & \\
\hline Pranata computer & 18 & \\
\hline Pustakawan & 2 & \\
\hline Arsiparis & 2 & \\
\hline Pranata humas & 4 & \\
\hline Statisi & 2 & \\
\hline Piñata laboratorium & 2 & \\
\hline Pentuluh sosial & 3 & \\
\hline Penyuluh KB & 4 & \\
\hline TOTAL & 467 & $99.36 \%$ \\
\hline
\end{tabular}

Sumber Data: BKD-Diklat Kab. Gorontalo 2009

Berdasarkan tabel diatas, tahun anggaran 2009 pemerintah Kabupaten Gorontalo menetapkan formasi pelamar umum 470 orang dengan angka penerimaan yang cukup tinggi 48.93\% pemerintah Kabupaten Gorontalo lebih menekankan depada tenaga kependidikan dengan pertimbangan bahwa masih kurangnya tenaga pendidik yang ada di Kab. Gorontalo. Formasi tertinggi kedua adalah tenaga kesehatan 29.36\% hal ini disebabkan karena di Kab. Gorontalo terdapat 1 (satu) Rumah Sakil yang terletak di kec. Limboto. Sedangkan untuk tenaga teknis pemerintah Kab. Gorontalo menetapkan $21.06 \%$ yang tersebar pada masing-masing pemerintahan di Kab. Gorontalo.

Untuk tahun anggaran 2010 pemerintah Kabupaten Gorontalo menetapkan formasi pelamar umum sebanyak 270 orang. Untuk lebih jelasnya dapat dilihat pada tabel berikut:

Tabel 5 : Rincian Pelamar umum yang terangkat menjadi CPNS Kab. Gorontalo tahun 2010

\begin{tabular}{|l|l|l|l|}
\hline No. & Bidang Tugas dan Keahlian & Jumlah & Presentase \\
\hline 1 & Tenaga Kependidikan & 85 & $34.69 \%$ \\
\hline 2 & Tenaga Kesehatan & 114 & $46.53 \%$ \\
\hline 3 & Tenaga Administrasi & 46 & $18.77 \%$ \\
\hline \multicolumn{2}{|l}{ TOTAL } & 245 & \\
\hline
\end{tabular}

Sumber Data : BKD-Diklat Kab. Gorontalo 2014 


\subsection{Mekanisme Penerimaan Calon Pegawai Negeri Sipil Oleh BKD-Diklat Kabupaten Gorontalo}

Realitas yang terjadi di berbagai daerah pelaksanaan penerimaan Calon Pegawai Negeri Sipil, dimana sejumlah ketentuan pelaksanaan meski telah diatur dalam Peraturan Perundang-undangan yang seharusnya dipedomani/dijalankan oleh pihak-pihak terkait namun dalam kenyataannya kurang optimal. Hal ini terlihat dalam beberapa praktek pelaksanaannya dimana terdapat beberapa hal yang seharusnya ditransparansikan dan dilaksanakan secara akuntabel sebagaimana tuntutan peraturan perundang-undangan namun justru cenderung disalah artikan dan tidak dilaksanakan secara konsisten.

Dengan melihat kondisi yang terjadi, Pemerintah Kab. Gorontalo menetapkan Peraturan Buti No. 41 Tahun 2007 tentang pelaksanaan Peraturan Daerah No. 20 Tahun 2007 Tentang Pembentukan organisasi dan tata kerja BKD-Diklat Kab. Gorontalo. Sedangkan tugas dan fungsi BKDDiklat dalam hal mekanisme penerimaan sesuai denan Peraturan Pemerintah No. 98 Tahun 2000 Jo Peraturan Pemerintah No. 11 Tahun 2002 tentang Pengadaan Pegawai Negeri Sipil dengan memperhatikan ketentuan yang ditetapkan dalam Undang-Undang No. 43 Tahun 1999 Tentang Pokokpokok Kepegawaian.

Data Quisioner 21 responden yang peneliti sebar diberbagai kalangan baik masyarakat umum, masyarakat yang pernah menjadi CPNS Kab. Gorontalo tetapi tidak ditetapkan menjadi PNS serta berbagai unsure yang turut menilai bagaimana fungsi BKD-Diklat Kab. Gorontalo dalam penyelenggaraan penerimaan dapat dilihat lebih rinci pada tabel dibawah ini.

Tabel 6 : Fungsi BKD-Diklat dalam penerimaan dan Penetapan Calon Pegawai Negeri Sipil (CPNS) Kab. Gorontalo

1. Jawaban Responden Kategori (Efektif)

\begin{tabular}{|l|l|c|c|}
\hline NO & \multicolumn{1}{|c|}{ Indikator } & Jumlah & Presentase \\
\hline 1 & $\begin{array}{l}\text { Transparan dalam pengumuman, } \\
\text { ujian seleksi serta penetapan CPNS }\end{array}$ & 9 & \multirow{2}{*}{$32 \%$} \\
\hline 2 & $\begin{array}{l}\text { Tidak adanya diskriminasi dalam } \\
\text { pendaftaran dan penetapan CPNS }\end{array}$ & 2 & \\
\cline { 1 - 3 } 3 & Sesuai dengan kompetensi & 5 & \\
\hline
\end{tabular}

Sumber : Data Primer setelah diolah, 2014

2. Jawaban Responden Kategori (Kurang Efektif)

\begin{tabular}{|l|l|c|c|}
\hline NO & \multicolumn{1}{|c|}{ Indikator } & Jumlah & Presentase \\
\hline 1 & $\begin{array}{l}\text { Transparan dalam pengumuman, } \\
\text { ujian seleksi serta penetapan CPNS }\end{array}$ & 15 & \multirow{2}{*}{$50 \%$} \\
\hline 2 & $\begin{array}{l}\text { Tidak adanya diskriminasi dalam } \\
\text { pendaftaran dan penetapan CPNS }\end{array}$ & 6 & \\
\hline 3 & Sesuai dengan kompetensi & 4 & \\
\hline
\end{tabular}

Sumber : Data Primer setelah diolah, 2014

3. Jawaban Responden Kategori ( Tidak Efektif) 


\begin{tabular}{|l|l|c|c|}
\hline NO & \multicolumn{1}{|c|}{ Indicator } & Jumlah & Presentase \\
\hline 1 & $\begin{array}{l}\text { Transparan dalam pengumuman, } \\
\text { ujian seleksi serta penetapan CPNS }\end{array}$ & 6 & \multirow{2}{*}{$18 \%$} \\
\hline 2 & $\begin{array}{l}\text { Tidak adanya diskriminasi dalam } \\
\text { pendaftaran dan penetapan CPNS }\end{array}$ & 2 & \\
\hline 3 & Sesuai dengan kompetensi & 1 & \\
\hline
\end{tabular}

Sumber : Data Primer setelah diolah, 2014

Dari data primer diatas, $50 \%$ responden menilai fungsi BKD-Diklat Kab. Gorontalo dalam penerimaan CPNS kurang efektif meskipun 32\% responden menilai bahwa fungsi BKD-Diklat Kab. Gorontalo pada dasarnya sesuai dengan ketentuan yang ada.

Berdasarkan hasil wawancara Peneliti di kantor BKD-Diklat Kabupaten Gorontalo dalam penyelenggaraan penerimaan Calon Pegawai Negeri Sipil dilaksanakan dalam rangka mencari calon pegawai yang memiliki integritas, kredibilitas dan kapabilitas bagus yang diharapkan mampu memberikan kontribusi tinggi bagi penyelenggaraan Negara (wawancara 20 Maret 2014).

\section{PENUTUP}

\section{1 kesimpulan}

Berdasarkan hasil penelitian penulis di Kantor BKD-Diklat Kabupaten Gorontalo mengenai penerimaan Calon Pegawai Negeri Sipil di lingkungan Kabupaten Gorontalo, penulis meberikan kesimpulan sehubungan dengan Fungsi Badan Kepegawaian Daerah Pendidikan dan Latihan Kabupaten Gorontalo dalam Penyelenggaraan Penerimaan Calon Pegawai Negeri Sipil Kurang Efektif, karena Standar Pelayanan Minimal belum dijadikan sebagai sebuah acuan yang diterapkan pada sistem pendayagunaan aparatur. Mekanisme Penerimaan Calon Pegawai Negeri Sipil dalam kenyataannya kurang transparansi dan akuntabel.

5.2 Saran

a) Badan Kepegawaian Daerah Pendidikan dan Latihan Kab. Gorontalo hendaknya meningkatkan kenerja dalam penyelenggaraan fungsinya khususnya dalam penyelenggaraan penerimaan atau pengangkatan Calon Pegawai Negeri Sipil.

b) Dalam proses Penyelenggaraan Penerimaan, sebaiknya Pemerintah Kabupaten Gorontalo lebih memperhatikan apa saja yang akan dilakukan dalam penerimaan tersebut. pelaksan penerimaan seharusnya dilakukan secara transparansi dan akuntabel.

c) Dalam system pendayagunaan aparatur diharapkan Pemerintah Kab. Gorontalo lebih khusus lagi BKD-Diklat dalam penerimaan CPNS dapat merekrut pegawai sesuai kebutuhan berdasarkan keahlian sesuai dengan formasi yang ada

\section{REFERENSI}

Buku

Abdulla,HMS, Birokrasi dan pembangunan Nasional: Studi tentang peran birokrasi dalam Implementasi Program pembangunan di Sulawesi Selatan, Universitas Hasanuddin Ujung pandang. 1985. 
Abdurachman..Prinsip-prinsip Manajemen Dalam Pemerintahan, Penerbit Raja Grafindo Persada, Jakarta, 1987.

Agus Dwiyanto, Mewujudkan Good Governance Melalui Pelayanan Publik, yogyakarta; Ghajah Mada University Pres, 2006.

Anonim, Sistem Administrasi Negara Republik Indonesia, LAN RI, Jakarta, 1997.

Bagong Suyanto dan Sutinah, Metode Penelitian Sosial, Kencana Predana Media Group. Jakarta,2007.

Basu Swastha, Manajemen Pemasaran Modern, Gunung Agung.Jakarta,2003,

Budiarjo, Dasar-dasar Imu Politik, Gramedi,2004.

C.S.T.Kansil, ,Pokok-Pokok Hukum Kepegawaian republik Indonesia,Jakarta:Pradnya Paramith, 1979.

Danim.S. Metode Penelinitian untuk Ilmu-Ilmu Perilaku. PT. Bumi Aksara Jakarta, 1997.

Darma,. Manajemen Kepegawaian dan Sistem Rekruitmen Pegawai di Indonesia. Penerbit Liberty, Jakarta, 2004.

Djohermansyah, Djohan, Fenomena Pemerintahan, PT. Yasrif Watampone, Jakarta, 1997.

Dan William N, Analisis Kebijakan Publik, PT. Hanindita Graha Widya Yogyakarta,2003.

Dan William N, Analisis Kebijakan Publik. Edisi Kedua PT Hanindita Graha Widya Yogyakarta,2005.

Dwiyanto, Agus. Mewujudkan Good Governance melalui Pelayanan Publik, Gadja Mada University Press, Yogyakarta, 2005

Peraturan Perundang-undagan

UU No. 32 Tahun 2004 Tentang Pemerintahan Daerah

UU No. 43 Tahun 1999 tentang Pokok-Pokok Kepegawaian

UU No. 5 Tahun 2014 tentang Aparatur Sipil Negara.

Peraturan Pemerintah No. 48 Tahun 2005 Jo. Peraturan Pemerintah No. 56 Tahun 2012 Tentang Pengangkatan Tenaga Honorer Menjadi Calon Pegawai Negeri Sipil

PERDA No. 20 Tahun 2007 Tentang Pembentukan Organisasi dan tata kerja Badan Kepegawaian Daerah

PERBUB No. 47 Tahun 2007 Tentang pelaksanaan Peraturan Daerah NO. 20 Tahun 2007 Tentang pembentukan Organisasi dan Tata Kerja BKD-Diklat Kab. Gorontalo.

\section{Penelitian Terdahulu}

Roy Marten Moonti. 2013. Judul Tesis "Efektifitas Pelayanan Publik Berkenaan Dengan Ijin Mendirikan Bangunan (IMB) Dalam Rangka Mewujudkan Good Governance (Studi Di Kota Gorontalo)".

Muchmad Bilondatu. 2013. Judul Skripsi "PeranBadan Kepegawaian Daerah Dalam Penyelenggaraan Penerimaan Calon Pegawai Negeri Sipil (studi di Badan Kepegawaian Daerah dan Latihan Kabupaten Gorontalo) ".

Indra Fibiona, 2013. Artikel "Analisis Kelebihan dan Kekurangan Recruitment CPNS Melalui Computer Assissted Test oleh BKN dalam rangka Mewujudkan Good Governance". 